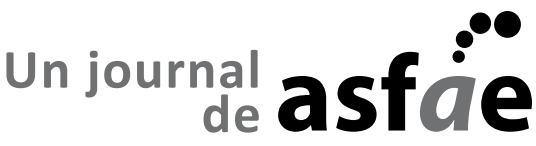

$\mathbf{m b r}$

\section{THE KEY ROLE OF CONSUMERS' INVOLVEMENT: THE CASE OF ORGANIC FOOD CONSUMPTION}

\author{
EL PAPEL CLAVE DE INVOLUCRAR A LOS CONSUMIDORES: \\ EL CASO DEL CONSUMO DE ALIMENTOS ORGÁNICOS
}

\author{
Nataly Levesque ${ }^{\mathrm{a}}$, Frank Pons ${ }^{\mathrm{b}}$ \\ Classification: Empirical paper - research \\ Received: June 27, 2020 / Revised: January 8, 2021 / Accepted: April 6, 2021
}

\begin{abstract}
This paper aims to provide a better understanding of conditions that influence the gap between positive attitude and intention towards organic food products and actual behaviour regarding these products. Thus, we propose an extended version of the Theory of Planned Behaviour (TPB) to explain parts of this gap and we highlight the crucial role played by consumers' involvement as a moderator. A structural equation modelling was performed, and the statistical analysis of a sample of 1327 French consumers supports our organic food products buying behaviour model. The results showed that the difference between the means of actual behaviour was highly different between lowand high-involvement consumers. More specifically, high-involvement consumers express more positive attitudes towards buying organic food products, perceive higher subjective norms and behavioural control, they have higher behavioural intention, and buy organic food products more frequently. Additionally, the results indicated that, compared to low-involvement consumers, high-involvement consumers regard organic food products as more attractive, healthier, tastier, and with higher value. We proposed some marketing strategies to help managers to better promote the organic food products market and, in turn, increase their revenues. For example, marketers therefore have a vested interest in increasing consumer involvement, and, among other things, they can do so by educating them (i.e., highlighting the benefits of consuming organic foods). Moreover, since high-involvement customers have positive attitude-intention and behaviour, they can be allies for marketers through their influence (social norms). Thus, we suggest the use of digital influencers to endorse organic food.
\end{abstract}

Keywords: theory of planned behaviour, involvement, organic food consumption, consumer behaviour, France, structural equation modelling.

\section{Resumen}

El objetivo de este artículo es proporcionar una mejor comprensión de las condiciones que influyen en la brecha entre la actitud positiva y la intención hacia los productos alimenticios orgánicos y el comportamiento real con respecto a estos productos. Por tanto, proponemos una versión extendida de la teoría del comportamiento planificado (TPB, por su sigla en inglés) para explicar partes de esta brecha y destacamos el papel crucial que desempeña la participación de los consumidores como moderadores. Se aplicó un modelo de ecuación estructural y el análisis estadístico de una muestra de 1327 consumidores franceses para respaldar nuestro modelo de comportamiento de compra de productos alimenticios orgánicos. Los resultados mostraron que la diferencia entre la media del comportamiento real era

a Laval University, Faculty of Business Management. Quebec City, Canada. Corresponding author. Email: nataly.levesque.1@ulaval.ca

b Laval University, Faculty of Business Management. Quebec City, Canada. Email: doyen@fsa.ulaval.ca 
muy diferente entre los consumidores de baja y alta involucración. Más específicamente, que los consumidores altamente involucrados expresan una actitud más positiva hacia la compra de productos alimenticios orgánicos, perciben normas subjetivas y control del comportamiento más altas, una mayor intención de comportamiento y también compran productos alimenticios orgánicos con mayor frecuencia. Además, los resultados indicaron que, en comparación con los consumidores de baja involucración, los consumidores de alta involucración consideran los productos alimenticios orgánicos como más atractivos, más saludables, más sabrosos y con mayor valor. Propusimos algunas estrategias de marketing para ayudar a los gerentes a promover mejor el mercado de productos alimenticios orgánicos y aumentar sus ingresos. Por ejemplo, los especialistas en marketing tienen un interés personal en aumentar la involucración de los consumidores y, entre otras cosas, pueden hacerlo educándolos (es decir, destacando los beneficios de consumir alimentos orgánicos). Además, dado que los clientes altamente involucrados tienen una actitud-intención y un comportamiento positivos, pueden ser aliados de los especialistas en marketing a través de su influencia (normas sociales). Por tanto, sugerimos el uso de influenciadores digitales para respaldar la comida orgánica.

Palabras clave: Teoría del comportamiento planeado, involucración, consumo de alimentos orgánicos, comportamiento del consumidor, Francia, modelo de ecuaciones estructurales.

\section{Introduction}

Food consumption is at the base of human needs and represents an important part of our everyday life (Gottschalk \& Leistner, 2013). Eating is essential, but also a central hedonistic activity that guides our behaviour (Kringelbach, 2004). Indeed, the percentage of consumer spending on food, still represents a critical and an increasing part of family budgets. For example, the share of consumer expenditure spent on food products, measured as the percentage of total consumer expenditure per person (not include alcoholic beverages or tobacco) is $13 \%$ in France, $9 \%$ in Canada, and $6 \%$ in the USA (United States Department of Agriculture, 2016). The current role played by food concerns in our everyday life is the result of continuous evolution and the fact that consumption has changed considerably over the years boosted by social, economic, environmental and health factors. For instance, consumers place an increasing emphasis on the ethical and ecological characteristics of food processing (MAPAQ, 2015). Knowing the origins of food products (e.g., organic) is now one of the most important criteria in the choice of food products (Observatoire de la consommation responsable, 2016). Statista (2020) has shown that the demand for organic food increased from $3.4 \%$ in 2010 to $5.7 \%$ in 2018 , compared to the total food sales in the United States. Thus, interest in organic food consumption has steadily risen over the past two decades (Kushwah et al., 2019; Massey et al., 2018; RodríguezBermúdez et al., 2020; Tandon et al., 2020), and there is a continuing trend towards organic food consumption in many industrialized countries (Janssen, 2018).

In early 2019, 93 countries had regulations for organic farming and the global organic market was estimated at nearly $€ 92.8$ billion in 2017 and exceeded $€ 100$ billion in 2018. The organic area cultivated worldwide was estimated at nearly 70 million hectares at the end of 2017 . It represented $1.4 \%$ of the total agricultural area of the countries surveyed. Nearly 2.9 million certified organic farms were registered in 2017 (Agence Bio, 2020a). More specifically, in 2018, the European Union (EU) organic food market exceeded $€ 40$ billion. More than 325,000 EU farms were cultivating more than 13.8 million hectares organically. Organic food represented about $7.5 \%$ of the EU utilized agricultural area in 2018 , $(7.2 \%$ in 2017). France was in second place for areas of organically grown food, only behind Spain (Agence Bio, $2020 b$ ). Therefore, leading to the development of the organic food market's reinforcement of a new paradigm called green marketing (Bryła, 2016).

As noted in the literature, organically produced food is healthier, more nutritious and tastes better (Aschemann-Witzel \& Niebuhr Aagaard, 2014; Krystallis \& Chryssohoidis, 2005). As a result, consumers have developed a positive attitude towards the consumption of organic foods (Al-Swidi et al., 2014; Massey et al., 2018). On the other hand, although the organic food market appears to be lucrative, the truth is that retailers only reach a fraction of the potential consumers (Gleim et al., 2013). Several studies noted that consumers generally express positive attitudes and intention to buy organic food, but their purchasing rate is still low (Aschemann-Witzel \& Niebuhr Aagaard, 2014; D'Astous \& Legendre, 2009; Massey et al., 2018; Tarkiainen $\&$ Sundqvist, 2005). Past literature has revealed several factors that could explain this gap. For example, the main barriers are lower availability, lack of relevant information (Tandon et al., 2020), price (Katt \& Meixner, 2020; Rodríguez-Bermúdez et al., 2020), as well as a lack of confidence in organic products (quality, authenticity, cer- 
tification, etc.) (Britwum et al., 2021; Chiu et al., 2019; Tandon et al., 2020; Wojciechowska-Solis \& Soroka, 2017). Obviously, this gap is truly problematic for both marketers who want to understand the consumers' motivation, as well as the organic food industry which tries to better understand consumer behaviour (Janssen, 2018; Peattie, 2010; Scalco et al., 2017).

Literature shows that, when it comes to buying organic products, consumers mention the following main criteria: 1) price; e.g., fair price, fits the budget (Magnusson et al., 2001; Tarkiainen \& Sundqvist, 2005; Zanoli \& Naspetti, 2011); 2) aspect of quality; e.g., attractiveness, healthy, tasty, high value (Hjelmar, 2011; Lee \& Hwang, 2016; Ngobo, 2011; Vassallo et al., 2016); 3) availability; e.g., limited (Aertsens et al., 2009; Żakowska-Biemans, 2011); 4) social influences; e.g., peer pressure (Bartels \& Reinders, 2010; Gottschalk \& Leistner, 2013); and 5) knowledge; e.g., what consumer's know about organic food (Berger \& Mitchel, 1989; Britwum et al., 2021; Fotopoulos \& Krystallis, 2002; Krystallis \& Chryssohoidis, 2005; Laroche et al., 2001; Liu, 2007; Magnusson et al., 2001; Van Kerckhove et al., 2011). Similar to several product categories, consumers often adopt desirable behaviours when their perceived benefit-cost ratio of purchasing a given product is higher than other alternatives on the market (Geller, 1992; Peattie, 2010). In this line of studies, previous research suggests that consumers' attitudes toward the environment is a very good predictor of their willingness to pay more for green products (Britwum et al., 2021; Fotopoulos \& Krystallis, 2002; Krystallis \& Chryssohoidis, 2005; Laroche et al., 2001; van Doorn \& Verhoef, 2011).

Furthermore, and at the heart of our study, consumers involved in sustainable products (e.g., organic) display more search effort to ensure their availability (Aertsens et al., 2009; Tarkiainen \& Sundqvist, 2005) and perceived organic food as high-quality products (Hjelmar, 2011; Yiridoe et al., 2005). According to Kushwah et al. (2019), consumer involvement refers to the extent to which consumers are involved in the buying of the organic food products. "It is an important concept in consumer marketing because it provides a basis for motivation, which can explain various behavioural outcomes of consumers" (Barber et al., 2009, p. 60). Thus, involvement is more than familiarity or knowledge experience with this type of food: involvement could describe specific feelings about a product (e.g., enthusiasm, worry) (Barber et al., 2009; Katt \& Meixner, 2020).

As part of this research, we chose the classification of involvement according to low and high involvement consumer behaviour (Engel \& Blackwell, 1982; Pieters et al., 1995; Zaichkowsky, 1985). More specifically, since the present paper focuses on the behaviour of interest, which is the consumers' choice for organic food, the concept of involvement refers to purchase involvement. Additionally, behavioural intentions of consumers who are highly involved is more consistent with their attitudes than behavioural intentions of low-involvement consumers. Hence, involvement is a driver for modelling attitude-intention (Petty et al., 1983) and intention-behaviour correspondence (Pieters et al., 1995). Therefore, we believed that the mobilization of involvement concept would be a good way to better understand the motivations that influence the development of certain behaviours (Teng \& Lu, 2016) (i.e., organic food consumption). Furthermore, the social identity theory plays an important role in the acceptance of new products. It is a social psychological analysis of the role of self-conception in group membership, group processes, and intergroup relations (Hogg, 2020). In fact, social identification is a strong predictor of human behaviour (Bartels \& Reinders, 2010; Huotilainen et al., 2006; Tajfel, 1974). Moreover, Chiu et al. (2019) mentioned in their study the social comparison (online) and its influence on consumers' citizenship behaviour towards organic foods. Finally, studies demonstrated that knowledge is correlated with referring others, social acceptability, and subjective norm, all of which influence intentions and behaviour (Liu, 2007; Sapp, 1991).

In terms of food choices, the theory of planned behaviour (TPB) (Ajzen, 1985, 1991) built on a strong and rational conceptualization (Aertsens et al., 2009) is one of the most widely used models to predict and understand food consumption behaviours (Aertsens et al., 2009; Dean et al., 2008; Vermeir \& Verbeke, 2006). This theory states that: "human behaviour is a function of behavioural intention that is formed by the combination of attitudes toward the behaviour, subjective norms, and the person's perception of behavioural control" (Dean et al., 2008, p. 2089). As identified by Vassallo et al. (2016), the TPB has been broadly applied to various consumer behaviours, including food choice, like organic food; meta-analyses confirmed the predictive efficacy of this model (e.g., Aertsens et al., 2009; Beale \& Manstead, 1991; Conner \& Sparks, 1996; Shepherd \& Raats, 1996; Sparks \& Shepherd, 2002; Towler \& Shepherd, 1992; Vermeir \& Verbeke, 2006). Thus, TPB represents a solid psychological framework to understand the motivations and process behind food choice in the sustainable consumption context (Peattie, 2010).

On the other hand, several studies have shown that involvement increases attitude-behaviour coherence (Nederhof, 1989) and moderates the attitude-intention relationship (Petty et al., 1983), as well as intention-behaviour 
(Pieters et al., 1995). Despite the interest of this variable in the consumer cognitive process (Kokkinaki, 1999; Nederhof, 1989; Rothschild \& Gaidis, 1981) in the context of organic food, very limited attention has been paid to the moderating effects of involvement applied to the TPB model (Aertsens et al., 2009; Tarkiainen \& Sundqvist, 2009; Vermeir \& Verbeke, 2006). Thus, justifying the use of this model to test the moderating variable of involvement.

Since marketing is at the service of society by informing it of the availability of goods and services that will improve their quality of life (Barber et al., 2009), it is particularly relevant to explore this subject of public interest. Therefore, the purpose of our study is twofold. First, we question whether the TPB can contribute to explain the gap between attitude and behaviour in the context of organic food consumption. Specifically, we aim for a better understanding of how to narrow this gap and thus help to facilitate organic food consumption. A better understanding of organic consumers will help to serve the long-term interests of this industry and the stakeholders of food marketing (Bryła, 2016; Oates et al., 2012). Practitioners can use the results to understand and improve their strategies in accordance with the decision-making process of organic food consumers. Second, we want to test the moderating effect of consumer involvement in the organic food consumption process. To this end, we investigate the consumption of organic food products among 1327 consumers in France. Given that several studies on the subject have been conducted in majority with North American or Asian respondents (Britwum et al., 2021; Chiu et al., 2019; Clark et al., 2019; Teng \& Lu, 2016), we believe that the results of French people provide marketers with contextual information that will enable them to better serve consumers in the face of their organic consumption. In addition, it will be interesting to compare our results with those of studies using the TPB model in other cultural contexts. Moreover, we base our study on those (i.e., Hofstede et al., 2005; Hofstede \& Hofstede, 1984) who in particular highlight the differences between different nations and have demonstrated for years the existence of undoubtedly significant differences between nations.

The present paper begins with a literature review on both the TPB and involvement and includes our research hypotheses. Next, the conceptual framework is presented, followed by the empirical testing of the model using structural equation modelling. Afterwards, the research results are exposed, plus we discuss of academics and practitioner's implications. Finally, this article concludes with some suggestions of future research avenues.

\section{Theoretical framework}

Applying the Theory of Planned Behaviour to Organic Food Consumption

The theory of planned behaviour was developed by Ajzen $(1985,1991)$ advancing from the earlier theory of reasoned action (TRA) (Ajzen \& Fishbein, 1980; Fishbein \& Ajzen, 1975). Both models were designed to provide explanations of consumer behaviour through various informational and motivational influences (Conner \& Armitage, 1998). The TPB was developed in order to broaden the range of behaviours that can be explained by the TRA to include those that are under incomplete control (Kokkinaki, 1999), the perceived as well as actual control over the behaviour under consideration (Fishbein \& Ajzen, 1975). As explained earlier: "TPB is a psychological model that considers three fundamental aspects of human behaviour: personal attitude, subjective norms, and perceived behavioural control. These are the basic antecedents of the intention to engage in a certain behaviour, which in turn mediates their relationship with actual behaviour" (Scalco et al., 2017). The TPB is depicted in Figure 1.

Figure 1. TPB framework

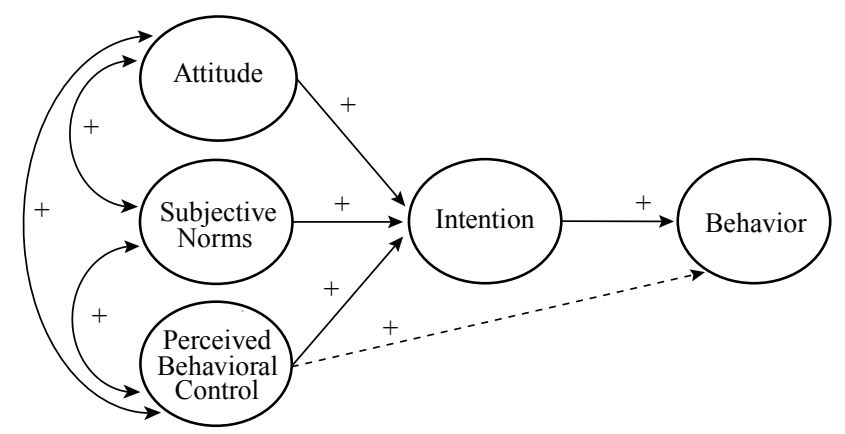

Note. Straight lines: direct link. Dotted line: direct link possible. Curved lines: correlation between variables

Source: Ajzen (1985).

To test the moderating variable of involvement, we looked for a model proven in the past. The literature confirmed the robustness of the original TPB model in predicting organic food consumption. According to Armitage \& Conner (2001), the canonical TPB model on average accounts for between the $39-50 \%$ of the variance in intention and $27-36 \%$ of the variance in behaviour. As noted by Scalco et al. (2017), a recent work on the value of the predictive model applied to organic food consumption could explain $62 \%$ of the variation in intention (Dowd \& Burke, 2013). 
Obviously, the objective of the practice is to generate desired behaviour in the intended consumer. Thus, with respect to a given target in a given situation, behaviour is a manifest and an observable response (Houme, 2009). According to Ajzen (1985), in the TPB, behaviour is a function of compatible intentions and perceptions of behavioural control. In short, that is why we chose the TPB model to test the moderating variable of involvement.

In the next section, we define and describe each of the TPB variables as well as their applications in the context of organic food products. As can be seen in the figure 1, intention is postulated as the variable that directly affects behaviour. Then, we will begin with the mediate contribution of this variable.

\section{Intention}

According to Fishbein and Ajzen (1975), the intention indicates what people plan to do in relation to a given object. It therefore indicates to what extent a person intends to engage in an action. More specifically, the intention to adopt a behaviour expresses the probability estimated personally by the individual to engage in the behaviour. It thus represents the motivational factors that determine human behaviour (Houme, 2009), and the intention to perform (or not) a behaviour is the immediate determinant of that action (Ajzen, 1985). Intentions and behaviour are held to be strongly related when measured at the same level of specificity in relation to the action, target, context, and time frame (Fishbein \& Ajzen, 1975). On the other hand, for the intention to predict the behaviour, it is to be measured according to two conditions; that is to say: 1) must reflect the respondent's intention as they exist, and 2) the behaviour must be under volitional control. According to the TPB, when behaviours pose no serious problems of control, they can be predicted through intention with considerable accuracy. Several studies found that the influence of intention to buy organic food products on behaviour is positive and significant (Saba \& Messina, 2003; Tarkiainen \& Sundqvist, 2005; Thøgersen, 2016). Thus, we hypothesize:

$\mathrm{H} 1$ : Consumer intention to buy organic food products predicts buying behaviour.

According to the TRA, intention results from three determinants, conceptually independent, but their combined actions determine consumer intention to act. This is the attitude towards the behaviour, perception of social pressures, namely subjective norms (SN) and perception behaviour control (PBC). Numerous studies report a significant positive relation between consumers' intention to purchase organic food and their attitude to organic food purchase, subjective norm, and PBC (Dean et al., 2008; Saba \& Messina, 2003; Thøgersen, 2016).

\section{Attitude}

Attitude refers to a set of beliefs, definied as: "belief as the subjective probability of a relation between the object of the belief and some other object, value, concept, or attribute" (Fishbein \& Ajzen, 1975). Ajzen (1991) defined the attitude towards the behaviour as the overall favourable or unfavourable evaluation of the behaviour and argued that people favour behaviours, they believe have largely desirable consequences, and form unfavourable attitudes towards behaviours they associate with mostly undesirable consequences. Therefore, attitude expresses the globally positive or negative evaluation about a certain behaviour: the more positive the attitude, the stronger the intention to express such a behaviour (Armitage \& Conner, 2001).

Studies on organic consumption found, in general, that consumers have positive atttiudes towards organic consumption (Magnusson et al., 2001). According to Thøgersen's (2016) and Saba and Messine's (2003) studies, especially beliefs about health, taste and environmental consequences have the strongest influence on attitudes towards buying organic food products. Consumers perceive a high value in organic food therefore making it more attractive (Magnusson et al., 2001). Whereas beliefs towards cost have relatively little influence on attitudes. These results are in line with other research on organic food, such as Yiridoe et al. (2005) and Aertsens et al. (2009).

According to the TPB, the more favorable the attitude towards the behavior, the stronger the intention to perform it (Ajzen, 1991). Several studies, Tarkiainen and Sundqvist (2005) among others, find a positive and significant relation between the attitude towards buying organic food and the intention to buy it (Aertsens et al., 2009). Scalco et al. (2017) noted that the strength of the association between attitude and behavioural intention in the case of organic food consumption largely varies among studies. According to several studies, (e.g., Al-Swidi et al., 2014; Onwezen et al., 2014) in general, the more favorable the attitude towards a behaviour, the stronger the individual's intention to perform it (Armitage \& Conner, 2001). Thus, we hypothesize:

H2: Positive attitude towards organic food products positively influences consumer intention to buy them. 


\section{Subjective Norms}

Subjective norms refer to the perception of some social pressure to engage or not engage in a particular behaviour (Aertsens et al., 2009). According to Scalco (2017), subjective norms are an expression of normative influence, which is related to what the most important referent individuals (parents, friends, co-workers) consider as an acceptable or unacceptable behaviour. As with attitudes, the perception of social norms is based on a series of beliefs. In fact, what other people in one's circle think about a specific subject is used to form one's beliefs, which is transformed into subjective norms. According to the TPB, subjective norms positively influence behavioural intention and subjective norms are important predictors of consumer intention to buy organic food products (Chen, 2007; Dean et al., 2008; Thøgersen, 2016). For example, "If consumers believe that those people important to them think organic foods are good, then they will have more intention of purchasing organic foods" (Chen, 2007, p. 1011). According to Vermeir \& Verbeke (2006) the importance of norms in describing and predicting human behaviour is evident in the use of the construct in many of the most influential theories of individual behaviour, such as the theory of reasoned action (Ajzen \& Fishbein 1980; Fishbein \& Ajzen 1975 ) and the theory of planned behaviour (Ajzen, 1988). Unlike law, which relies on coercive force to influence behaviour, norms constrain individual actions through collective expectations of behaviour (Cialdini \& Goldstein, 1998). Always in the context of organic food products, other authors found a significant causal path between subjective norms and attitude towards behaviour (purchase intention) (Al-Swidi et al., 2014; Tarkiainen \& Sundqvist, 2009). Thus, we hypothesize:

H3: Subjective norms positively influence consumer intention to buy organic food products.

Therefore, the first two factors that determine intention and ensuing predict behaviour, namely attitude and subjective norms, and reflect the perceived desirability of performing the behaviour. On the other hand, the third factor is perceived behaviour control (PBC) and reflects perceptions of whether the behaviour is personally controllable or not (Chen, 2007).

\section{Perceived Behaviour Control}

Ajzen (1985) extended the theory of reasoned action (TRA) (Fishbein \& Ajzen, 1975) to include a measure of perceived behavioural control (PBC). PBC refers to people's own perception of their ability to perform a given behaviour: "the rationale behind the addition of $\mathrm{PBC}$ was that it would allow prediction of behaviours that were not under complete volitional control" (Armitage \& Conner, 2001, p. 472). More specifically, the addition of $\mathrm{PBC}$ to the model provides information about the potential constraints on an action, as perceived by the consumer. So, PBC can help to explain why intentions do not always predict behaviour. Again, as with attitude and subjective norms, $\mathrm{PBC}$ is determined by beliefs, but now in terms of the performance of the given behaviour (Aertsens et al., 2009; Ajzen, 1985). So, it is expected that those who perceive more behaviour control will have more intention of performing that behaviour (Ajzen, 1991). Several studies supported the positive influence of $\mathrm{PBC}$ on the intention to buy organic food products (Dean et al., 2008). Moreover, perceived control over behaviour can be directly related to behaviour (Ajzen, 1991).

PBC synthesizes two concepts: locus of control (Rotter, 1954) and he self-efficiency (Bandura, 1977). Locus of control refers to the general belief of an individual influence the course of his or her life and to the perception that a person can perform a given action (Chen, 2007; Dean et al., 2008; Houme, 2009; Sparks \& Shepherd, 2002). For example: "consumers may not have the capability to readily identify organic food labels, thus influencing perceived behavioural control" (Chen, 2007, p. 1011). In this way, consumers desire clarity about organic product certifications and labels (Katt \& Meixner, 2020; Lee \& Hwang, 2016; Lockie et al., 2002). Trustworthiness is considered as a major emotional variable for the buyers of organic products (Britwum et al., 2021; Perrini et al., 2010) and a major inflectional factor (Lockie et al., 2002). Several researchers have looked at the trustworthiness variable and have shown its importance in the decision-making process relating to organic foods (Al-Swidi et al., 2014; Britwum et al., 2021; Khare \& Pankey, 2017; Zegler, 2016). In fact, consumers make decisions about purchasing organic foods and the prices they are willing to pay based on their confidence in these unobservable attributes (Britwum et al., 2021; Massey et al., 2018). Therefore, trustworthiness in a product influences the PBC, even though the consumer feels in full possession of his or her means because he or she is confident of making a considered choice, as well as on the positive attitude towards the product thanks to trustworthiness. Moreover, a lot of knowledge regarding the sustainable character of food consumption tends to be associated with high behavioural intention (Vermeir \& Verbeke, 2006). Therefore, when consumers trust organic food (i.e., promotional advertisements, label, product quality and authenticity), they are often willing to pay a high price for it (Britwum et al., 2021; Temperini et al., 2017). In contrast, consumers with a lack of knowledge 
or those who do not trust certifying organizations (Aertsens et al., 2009; Katt \& Meixner, 2020; Lee \& Hwang, 2016) are probably not willing to pay a premium price. Moreover, studies demonstrate the encouraging role of knowledge and note that a person sufficiently informed is more likely to be environmentally conscious and to adopt an eco-friendly behaviour (Halkier \& Bente, 1999; Katt $\&$ Meixner, 2020). Similarly, Liu (2007) stated that consumers who perceive themselves as knowledgeable about organic products consume more organic food.

Past research also recognized that the limited availability and the high price of organic products are mentioned as the most important reasons for not buying organic food products (Boccaletti \& Nardellab, 2000; Fotopoulos \& Krystallis, 2002; Magnusson et al., 2001; Tarkiainen \& Sundqvist, 2005; Zanoli \& Naspetti, 2011). In fact, consumers wish for convenience, such as products easily available in supermarkets or close to their house (Lockie et al., 2002). Concerning the economic aspect, consumers who are not very knowledgeable about organic food prefer more affordable prices (Vermeir \& Verbeke, 2006). Otherwise, the behaviour is perceived with difficulty and less controllable. According to Ajzen (1991), if the inhibitory factors are perceived realistically, the $\mathrm{PBC}$ will prove to be an important predictor of behaviour given its effect on intention. Moreover, when perceived control and effective control coincide, the PBC directly predicts behaviour (Houme, 2009). Thus, we hypothesize:

$\mathrm{H} 4$ : PBC over the purchasing of organic food products positively influences consumer intention to buy them.

H5: PBC over the purchasing of organic food products positively influences consumer buying behaviour.

The Ajzen (1985) model assumes that the antecedents may potentially correlate with each other (Scalco et al., 2017). Tarkiainen \& Sundqvist (2005) supported these relationships by singling out a significant positive path from subjective norms to attitude toward organic consumption. Based on these findings, we hypothesize that the combined actions of attitude, SN and PBC determine consumer intention to buy organic food. More specifically:

H6-a: Positive attitude and subjective norms are positively correlated and predict consumer intention to buy organic food products.

H6-b: Subjective norms and PBC are positively correlated predict and consumer intention to buy organic food products.
H6-c: Positive attitude and PBC are positively correlated and predict consumer intention to buy organic food products.

\section{Involvement}

According to (Celsi \& Olson, 1988; Petty et al., 1983), the concept of felt involvement refers to a consumer's overall subjective feeling of personal relevance. In fact, involvement is a state of motivation that affects the process of consumer attention and understanding, and then the meanings that follow. Stability, resistance to external influences, and the relevance in information processing are the essential characteristics of involvement (Celsi \& Olson, 1988; Petty et al., 1983; Richins \& Bloch, 1986; Zaichkowsky, 1985). Thus, involvement is activated when a product is perceived to be instrumental in meeting important needs, goals, and values (Vermeir \& Verbeke, 2006). In the case of organic food, most of the consumers are in a situation where the purchasing of organic products represents an ongoing focus that transcends situational influences (Richins \& Bloch, 1986). This can be labelled as an enduring involvement because it's more of a lifestyle than just an ordinary purchase.

Numerous theorists distinguish the consumer behaviour in dichotomous terms: low involvement consumer behaviour and high involvement consumer behaviour (Engel \& Blackwell, 1982; Pieters et al., 1995; Zaichkowsky, 1985). According to the Elaboration Likelihood Model (ELM) (Petty et al., 1983) when consumers have a high involvement with an object/product, their attitude is affected via the central route, resulting from their diligent consideration of information that they feel is central to the true merits of a particular attitudinal position. Therefore, the consumer is motivated. On the other hand, when consumers have low involvement with an object/ product, their attitude changes do not occur because they have personally considered the pros and cons, but because the attitude is associated with simple positive or negatives cues (Petty et al., 1983). Therefore, a consumer has a lack of ability or motivation. In line with the ELM model, behavioural intentions of a consumer who is highly involved is more consistent with his or her attitudes than behavioural intentions of a low-involvement consumer. Consequently, high levels of involvement are related to a high degree of consistency between attitudes and intentions (Petty et al., 1983; Pieters et al., 1995).

Petty et al., (1983) stated that the more involved an individual is with an attitude object, the more cognitive efforts he or she allocates to understanding it and making decisions about it. Therefore, having high levels of 
involvement leads to attitudes based on greater elaboration of relevant information, the attitudes that are more accessible, certain, and based on more knowledge and thus better predictors of intentions (Petty et al., 1995). Furthermore, intentions formed under high cognitive elaboration conditions are more consistent with subsequent behaviours (Bagozzi \& Yi, 1988). It is the perspective used in this study where we consider involvement as a holistic concept that can be captured by the enduring level of relevance and focus of a given consumer.

\section{Moderation Role of Involvement Applying to Organic Food Consumption}

\section{Attitude and Intention}

Foods and weekly shopping groceries are usually considered as low-involvement products and the buying decisions involved are based on routine or limited problem solving (Aertsens et al., 2009; Baharrell \& Denison, 1995; Costa et al., 2004; Fisher \& De Vries, 2008; Hoyer, 1984). This is also a reason why consumers do not buy organic food regularly. In fact, despite positive attitudes "such ideologically formed attitudes are not present in habitual, low-involvement shopping activities" (Tarkiainen \& Sundqvist, 2009, p. 844). We can associate this low involvement.

Despite this routine low involvement pattern, one can presume that the nature of organic food products that appeal to a more complex set of values such as health consciousness and environmental friendliness may lead consumers to attentively consider the decision to buy these products. In addition, organic food is more expensive than conventional food products (Schifferstein \& OudeOphuis, 1998; Tarkiainen \& Sundqvist, 2005). According to Schifferstein \& OudeOphuis (1998), the differences between buyers and non-buyers of organic food is partly due to their lifestyles. More specifically, consumers' attitudes towards organic food results from an ideology related to their deeper value systems. Furthermore, the level of involvement dictates the complexity of the decision-making process. It is suggested that consumers concerned with healthy diets and environmental degradation (i.e., high-involvement consumers) are: 1) willing to pay a high premium for organic products (Gil et al., 2000; Loureiro et al., 2012); 2) display more effort to search for the availability of organic products and information (Vermeir \& Verbeke, 2006); and 3) evaluate product characteristics, and make a cognitive process of their internal values (Beatty \& Smith, 1987; Pieters et al., 1995; Tarkiainen \& Sundqvist, 2005). Therefore, they perceived a high quality in organic food (Hjelmar, 2011). These findings are very interesting given that these three points represent some of those discussed earlier in the PBC section. Thereby, the literature largely demonstrates that involvement moderates' attitude-intention (Petty et al., 1983) and intention-behaviour correspondence (Pieters et al., 1995). Thus, we hypothesize:

H7-a: The more consumers are involved with organic food products, the stronger the influence of their attitude on their buying intention of organic food products.

H7-b: The more consumers are involved with organic food products, the stronger the influence of their intention to buy on their buying behaviour of organic food products.

\section{Subjective Norms}

Research has also studied the moderating role of involvement on the subjective norm-intention relationship. Some studies found that consumers who are less-involved with a product show greater subjective norm-intention consistency (Nederhof, 1989; Petersen \& Dutton, 1995). Some others found the opposite direction. According to the literature, when making a behavioural decision, the consideration of subjective norms is an effortful process and thus individual differences in cognitive activity may moderate the role of these norms in forming the behavioural intention (Trafimow, 2000). Since high involvement individuals allocate more cognitive efforts to their decisions (Petty et al., 1983), it implies they are likely to show greater subjective norm-intention consistency. Klöckner et al. (2003) also argued that having a low level of involvement limits the search for information and may hinder the activation of norms in shaping behaviour. We extend these findings to the organic food consumption context, but due to conflicting theories about the direction of the moderating effect of involvement on the subjective norm-intention relationship, we make no hypothesis about its direction. Thus, we hypothesize:

H7-c: Involvement moderates the subjective normintention relationship.

\section{$P B C$}

According to Chiou, (1998) and Flynn and Goldsmith (1999), people with high subjective product knowledge have more confidence in their consumption behaviour. Given that their attitude towards the behaviour already reflects their confidence, the attitude can outweigh the effect of the PBC (Vermeir \& Verbeke, 2006; Yiridoe 
et al., 2005). Therefore, the effect of the PBC on intention will be weaker when the consumer has high subjective product knowledge. On the other hand, people with low subjective product knowledge have less confidence in their consumption behaviour. So, when forming intention, attitude will not be the dominating antecedent and PBC will become the important factor for consideration. Based on these reasonings, Chiou (1998) suggested that subjective knowledge moderates' attitude-intention and PBC-intention relationships. Since subjective knowledge is highly correlated with involvement (Flynn \& Goldsmith, 1999; Park \& Moon, 2003), we believe that the effect of the PBC on intention will be stronger for consumers with lower levels of involvement. According to Houme (2009), the PBC predicts behaviour directly. We also believe that the influence of the PBC on behaviour will be stronger for consumers with a low level of involvement. Thus, we hypothesize:

H7-d: The more the consumer is involved with organic food products, the weaker the influence of the PBC on his or her buying intention.

H7-e: The more the consumer is involved with organic food products, the weaker the influence of the PBC on his or her buying behaviour.

Hence, involvement moderates the relative weight of predictor variables within the TRA and its extended versions, among others, TPB (Kokkinaki, 1999). Figure 2 presents our conceptual model and shows the 13 hypotheses about the causal relationships between different constructs.

Figure 2. The conceptual model and the research hypotheses

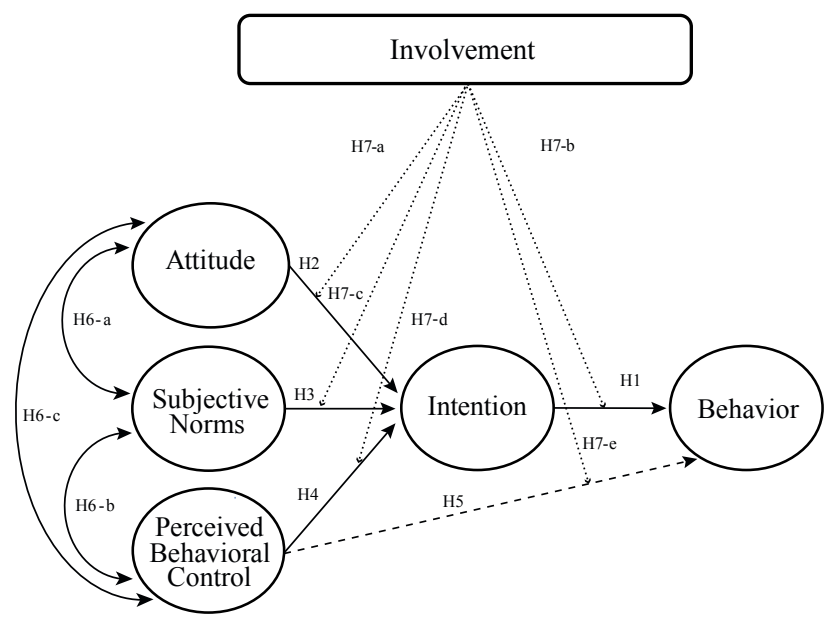

Note. Straight lines: direct link. Dotted line: direct link possible. Curved lines: correlation between variables. Dashed lines: moderating variable.

\section{Methodology}

\section{Respondents}

Our sample consisted of 1327 French respondents (Table 1). This sample was deemed appropriate for consistent validity and reliability (Tabachnick et al., 2007) (i.e., 10-15 respondents per item (Nunally, 1978). Almost 71.4 percent were female. The age of the respondents varied from 18 to 59 and the average age was 24 years old. Almost 73.4 percent had an income of less than $€ 20.000$. Thus, it was a young sample with limited financial resources. However, it consisted of educated people, as more than 27.7 percent had completed university education and more than 96.5 percent had college or university degrees. The average educational level was college and represented 68.8 percent.

Table 1. Descriptive statistics of the participants

\begin{tabular}{|c|c|c|c|c|c|c|c|}
\hline \multicolumn{2}{|c|}{$\begin{array}{l}\text { Age } \\
(\%)\end{array}$} & \multicolumn{2}{|c|}{$\begin{array}{c}\text { Level of } \\
\text { education }(\%)\end{array}$} & \multicolumn{2}{|c|}{$\begin{array}{c}\text { Gender } \\
(\%)\end{array}$} & \multicolumn{2}{|l|}{$\begin{array}{c}\text { Income } \\
(\epsilon)\end{array}$} \\
\hline $18-24$ & 64.3 & $\begin{array}{l}\text { Primary } \\
\text { school }\end{array}$ & 1.9 & Male & 28.6 & $<20.000$ & 73.4 \\
\hline $25-44$ & 34.6 & $\begin{array}{l}\text { High school } \\
\text { diploma }\end{array}$ & 1.6 & Female & 71.4 & $20.000-29.999$ & 8.8 \\
\hline \multirow[t]{3}{*}{$45-59$} & 1.1 & College & 68.8 & & & $30.000-49.000$ & 6.2 \\
\hline & & University & 27.7 & & & $50.000+$ & 3.3 \\
\hline & & & & & & Prefer not to say & 8.3 \\
\hline
\end{tabular}

Note. In France, revenues are recorded in Euros $(€)$.

\section{Procedure}

Data was collected on the Internet using a snowball sampling technique among various groups involved in food chat and blog groups by posting messages presenting the study as a university group project. The participation was fully voluntary. The initial questionnaire was in English as all the scales were back-translated (English-French) to ensure the items accuracy and consistency across languages (Mittal, 1995; McGorry, 2000). Given that online surveys generally have lower response rates than some other modes of collection (6-15\%) (Fan \& Yan, 2010), to encourage people to answer the questionnaire, a $€ 100$ prize was offered for a random participant that was chosen at the end of the study. To this end, people were asked to enter their e-mail addresses which also ensured that they did not answer the questionnaire more than once. We collected the data over a span of 6 weeks.

\section{Measurement}

The 25 items are divided into six constructs: attitude towards buying organic food products (ATT), subjective norms $(\mathrm{SN})$, perceived behaviour control (PBC), 
intention to eat organic food products (INT), involvement with organic food products (INV), and behaviour towards buying organic food products (BEH). Measures were adapted from studies applying TPB in the organic market or other specific markets, including low fat diet (Armitage \& Conner, 2001), organic food (Magnusson et al., 2001; Tarkiainen \& Sundqvist, 2005), exercising (Kellar \& Abraham, 2005; Kidwell \& Jewell, 2003; Mahon et al., 2006; Patch et al., 2005; Rhodes \& Courneya, 2003), organic coffee, bread and flour (Chen, 2007), food enriched with omega (Patch et al., 2005). The measure of involvement was adapted from (Mittal, 1995). At the end of the survey, we assessed the sociodemographic characteristics of our sample, like gender, age, and education. A pre-test of the questionnaire was carried out with a convenience sample (Cronbach's alpha and factorial analysis). Using face-to-face questionnaire interviews, the questionnaire was administered to 170 students-customers who do their own grocery shopping. The purpose of this quantitative pre-test was to assess the dimensionality of the scale as well as the reliability of the construct before launching the full data collection. A summary table with all the measures and their factor loadings is presented in Appendix 1.

\section{Preliminary analyses}

A confirmatory factor analysis was conducted on the full sample to assess the adequacy of the measurement model. The value of $\mathrm{S}-\mathrm{B} \chi 2$ is $300.56(\mathrm{p}=0.000)$, with 136 degrees of freedom. The $\chi 2 / \mathrm{df}$ ratio is 2.21 (below 3 ), suggesting a good fit of the model, according to Bentler and Bonett, 1980. The NNFI $=0.93$ is above 0.90, which means a good fit of the model to empirical data (Bentler, 2005). The comparative index CFI $=0.95$ is above 0.90 , the value recommended by Kline (2005) and Bentler (2005). Finally, the RMSEA $=0.041$ is smaller than the minimum value of 0.06 set by (Tabachnick et al., 2007). The fit indexes of the measurement model are all satisfactory, indicating that the fit of the empirical data to the hypothesized model is adequate. The values of Cronbach's alpha $(\alpha)$ vary between 0.73 and 0.95 , and are greater than 0.70 , the value recommended by Nunally (1978) and Tabachnick et al. (2007). Second, convergent validity was assessed, following the approach proposed by (Fornell $\&$ Larcker, 1981). The factors loadings $(\lambda)$ are all above 0.70 and the convergence AVE index (average variance extracted). Finally, the discriminant validity was also confirmed, as the squared correlations between each pair of constructs is less than the average variance extracted by the constructs (Fornell \& Larcker, 1981). The analyses performed on these latent variables indi- cated a reasonably good fit to the data, thus confirming the quality of the measurement model and allowed us to start the structural model's evaluation.

\section{Analysis and Results}

\section{Descriptive Statistics}

For descriptive statistics, all the items measuring respectively the five variables of the original TPB model plus the one we added (involvement) were averaged to provide the measurement of each individual construct (Table 2). For instance, the measure of attitude had the higher mean of these five variables. Although most respondents had a positive attitude towards buying organic products $(\mathrm{m}=4.516)$ and expressed an intention to buy them $(\mathrm{m}=4.077)$, the buying frequency was rather low $(m=3.672)$. These findings are in line with the past research on organic food product consumption (Magnusson et al., 2001) and confirm the gap that we are trying to explain. The mean of subjective norms is the lowest of all variables $(m=2.706)$, which means respondents perceived low social pressure from their family and friends to eat organic food products. The PBC was moderately low $(\mathrm{m}=3.902)$, which implies that respondents perceived not having a lot of control on their organic buying behaviour. Again, this finding is related to the literature: it is expected that those who perceive more behavioural control have more intention of performing this specific behaviour (Ajzen, 1991). Therefore, the PBC probably plays a role in the formation of the gap. Finally, involvement is high $(m=4.077)$ which means that consumers are relatively involved with organic food products.

Table 2. Means and SD scores among the measured variables

\begin{tabular}{lcc}
\hline \multicolumn{1}{c}{ Constructs } & Mean & SD \\
\hline Attitude & 4.516 & 1.202 \\
Involvement & 4.101 & 1.755 \\
Intention & 4.077 & 1.760 \\
PBC & 3.902 & 1.024 \\
Behaviour & 3.672 & 1.918 \\
Subjective Norms & 2.706 & 1.557 \\
\hline
\end{tabular}

\section{Hypothesis Testing}

\section{Structural Equations Modelling}

A structural equations modelling (SEM) was performed to test the conceptual model. Unlike traditional multivariate data analysis methods, SEM, a set of linear regressions, provides explicit estimates of measurement error and allows simultaneous testing of observed and latent 
variables (Fornell \& Larcker, 1981). The number of respondents is consistent with the literature in the context of SEM, i.e., a number greater than or equal to $n$, where $\mathrm{n}>\mathrm{p} *(\mathrm{p}+1) / 2$, or $\mathrm{p}$ represents the number of items (Roussel, 2005) $-1327>25 *(25+1) / 2=325$. Figure 3 presents the analysis of the structural model with unstandardized solution for this study, including the chisquare $\left(\chi^{2}\right)$ test and degrees of freedom (df), respectively $\chi 2: 577.06$, df: 150 , p: 0.000 . In addition, the results for nonparametric indices of fit are also introduced (CFI: 0.968, RMSEA: 0.051, GFI: 0.948, AGFI: 0.927). All these results indicate that the TPB model fits the overall data well (Bagozzi \& Yi, 1988) (Figure 3). In fact, our first hypotheses are supported except the direct effect of the PBC on behaviour (H5).

Figure 3. Analysis of the structural model with unstandardized solution

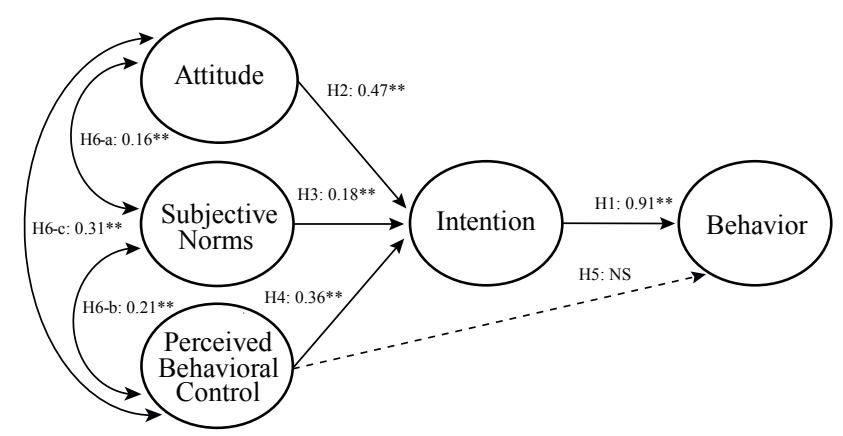

Note. ${ }^{* *} \mathrm{p}<0.000$. Straight lines: direct link. Dotted line: direct link possible. Curved lines: correlation between variables. Dashed lines: moderating variable.

\section{Testing for Moderator Effect of Involvement}

To examine the moderating role of involvement, we performed a multi-group analysis as suggested by Jöreskog \& Sörbom (1996). The groups (i.e., Low-Involvement (LI) participants and High-Involvement (HI) participants) are formed by dividing the full sample at the median value of the involvement variable (i.e., 4.0) (Baldauf et al., 2009). Table 3 displays the ANOVA estimates, comparing the mean scores of the measured variables for participants with low and high levels of involvement. This test is based on the Welch-test (Welch, 1947), since according to the Levene-test, the equality of variances could not be assumed (Härdle \& Simar, 2007).

The mean scores of all variables were significantly different between LI and HI consumers (participants). More specifically, consumers who are more involved in organic food products express a more positive attitude, perceive higher subjective norms and $\mathrm{PBC}$, have a higher behavioural intention, and buy organic food products more frequently. These findings are in line with the past research on organic food product consumption (Magnusson et al., 2001). We also compared the mean scores of underlying constructs of attitude and PBC between LI and HI consumers. The results indicate that, compared to the LI group, HI consumers regard organic food products as more attractive, healthier, tastier, and with higher value (including eating organic food products makes people feel good about themselves, and an enjoyable consuming experience). Furthermore, HI consumers believed that the price of organic food products is fair, purchasing them fits their budget, consuming them is convenient, their certifications are trustworthy, and, they know a lot about organic food products. Therefore, all mean scores of underlying constructs of attitude and PBC are higher for HI consumers. We will discuss these results in more detail in the next section.

Table 3. ANOVA estimation, comparing the mean scores of the measured variables for the low and high involvement groups

\begin{tabular}{|c|c|c|c|c|c|c|}
\hline & \multicolumn{2}{|c|}{ Low-Involvement } & \multicolumn{2}{|c|}{ High-Involvement } & \multirow[b]{2}{*}{ ANOVA $^{a}$} & \multirow[b]{2}{*}{$\mathbf{p}$} \\
\hline Constructs & Mean & SD & Mean & SD & & \\
\hline Attitude & 3.818 & 0.946 & 5.469 & 0.790 & 1195.075 & 0.000 \\
\hline $\begin{array}{l}\text { Subjective } \\
\text { Norms }\end{array}$ & 2.188 & 1.251 & 3.413 & 1.653 & 216.865 & 0.000 \\
\hline PBC & 3.522 & 0.892 & 4.421 & 0.964 & 307.351 & 0.000 \\
\hline Intention & 3.272 & 1.553 & 5.176 & 1.394 & 547.975 & 0.000 \\
\hline Behaviour & 2.92 & 1.765 & 4.681 & 1.631 & 352.237 & 0.000 \\
\hline
\end{tabular}

a The ANOVA is based on the Welch-test, since according to the Levene-test, the equality of variances could not be assumed. All variables were measured on a 7-point Likert scales.

Table 4 presents the model fit indices and estimated path coefficients of the multi-group analysis. The results of the chi-square test $(\chi 2)$ and degrees of freedom (df) are respectively, $\chi 2: 961.3$, df: 302 , p: 0.000 , and CFI: 0.971, RMSEA: 0.048, GFI: 0.951, AGFI: 0.927. Z-score is estimated based on (Baldauf et al., 2009; Paternoster et al., 1998) a statistical test for the equality of estimated coefficients. The results show that, in both low and high involvement groups, the proposed model fits the data well. Thus, the analytical results demonstrate that both paths are significantly different between the groups. Since all indices are better than the recommended values (Bagozzi \& Yi, 1988; Jöreskog \& Sörbom, 1996) the provided measures indicate a good fit. Otherwise, the moderating role of involvement in our model is supported and all our hypothesizes are validated (H7-a to H7-e). Although the PBC has no direct effect on the buying behaviour in the organic food products context (H5), for LI consumers, the moderating role of involvement has an effect on this relation (H7-e). We will discuss this result 
with more details in the discussion. Using the results, we are also able to determine the direction of H7-c. As shown in Table 4, the more the involvement with organic food products, the lower the subjective norm-intention relationship. This finding is in line with Nederhof, 1989 and Petersen and Dutton (1995). So even if HI consumers perceive higher subjective norms against organic food products, they only have a slight effect on their intention.

Table 4. Analysis of the structural mode; differences between the low and high involvement groups

\begin{tabular}{lcccc}
\hline \multicolumn{1}{c}{ Laths } & $\begin{array}{c}\text { Standardized } \\
\text { Estimate }\end{array}$ & t-value & $\begin{array}{c}\text { Standardized } \\
\text { Estimate }\end{array}$ & t-value \\
\hline $\begin{array}{l}\text { H7-a: Attitude à } \\
\text { Intention }\end{array}$ & $.21 * * *$ & 2.98 & $.59 * * *$ & 5.36 \\
$\begin{array}{l}\text { H7-b: Intention à } \\
\text { Behaviour }\end{array}$ & $.81 * * *$ & 6.52 & $.94 * * *$ & 17.85 \\
$\begin{array}{l}\text { H7-c: SN à } \\
\text { Intention }\end{array}$ & $.25 * * *$ & 3.12 & $.13 * *$ & 2.31 \\
$\begin{array}{l}\text { H7-d: PBC à } \\
\text { Intention }\end{array}$ & $.45 * * *$ & 4.21 & $.20 * * *$ & 2.87 \\
$\begin{array}{l}\text { H7-e: PBC à } \\
\text { Behaviour }\end{array}$ & $.18^{* * *}$ & 2.65 & $\mathrm{NS}$ & \\
\hline
\end{tabular}

$* * * \mathrm{p}<0.01, * * \mathrm{p}<0.05$.

\section{Concluding Discussion and Implications}

\section{Theory of Planned Behaviour}

This paper aims to contribute to a better understanding of the conditions that influence the gap between the high intention to buy organic food products and the low actual buying behaviour. Our results and the marketing strategies we provide will help to serve the long-term interests of this industry (Bryła, 2016; Oates et al., 2012). Practitioners can use the results to understand and improve their tactics in accordance with the decision-making process of organic food consumers. For this purpose, we mobilized the theory of planned behaviour (Ajzen, 1985), a well-known model widely used for his capacity to predict intention and consumer behaviour (e.g., Armitage \& Conner, 2001). In accordance with the TPB and the existing knowledge about the consumption of organic food products, the results indicated that attitude-intention, subjective norms-intention, $\mathrm{PBC}$-intention, and intention-behaviour relationships are all significantly positive. This finding is also a good support of the typical role of attitude in organic consumption process (Saba \& Messina, 2003) and supports the role of cognitive processes in organic food product buying behaviour (Tarkiainen \& Sundqvist, 2009). Surprisingly, the PBC would not have a direct effect on consumer behaviour in the organic food products context. Even if this hypothesis was not validated, the TPB proved its quality and continues to be a robust model to better understand consumer behaviour (Armitage \& Conner, 2001).

As expected, although most respondents had a positive attitude towards buying organic food products and expressed the intention to buy them, the buying frequency was rather low. These results confirmed the gap between intention-behaviour and is in line with the past research on organic food product consumption (e.g., Magnusson et al., 2001; Tae-Im \& Stoel, 2017). Moreover, we tested the correlation between antecedents of intention, namely attitude, subjective norms and PBC and they are all positively correlated. Therefore, their combined actions determine the consumer's intention to buy organic food products. Consequently, we can assume that indirectly, these antecedents play a role in the gap studied in our research. In fact, subjective norms and PBC can be incorporated into cognitive and behavioural components of attitude (Aertsens et al., 2009). For example, the relationship between subjective norms and attitude was significantly positive, which implies that attitudes towards organic food products "passes on" subjective norms among consumers. Then, people who think positively about organic food products can influence the attitude of other consumers (Tarkiainen \& Sundqvist, 2009). In other words, significant others (e.g., family, friends) affect the organic food products behaviour of a person, both through social pressure and attitude training. Seemingly, the same kind of relationship exists between attitude, subjective norms and PBC. Thereby, for practitioners, these findings imply that by increasing subjective norms and $\mathrm{PBC}$, they can enhance consumers' intention to buy organic food products directly or indirectly through attitude training. To do this, they can provide more information about their products, which will, in turn, increase consumers' confidence in their decision to buy organic products and reassure them about the quality, authenticity, price, etc.

\section{Extended Version of the Theory of Planned Behaviour}

Furthermore, in this paper we proposed an extended version of the TPB by examining the moderating role of involvement on the relationship between attitude-intention, subjective norms-intention, $\mathrm{PBC}$-intention, intention-behaviour, and $\mathrm{PBC}$-behaviour. This extension was based on the fact that the level of involvement dictates the complexity of decision-making processes (Tae-Im \& Stoel, 2017), the number of research and evaluation activities to be performed (Beatty \& Smith, 1987), as well as influencing the attitude strength, the attitude-intention, and intention-behaviour consistency (Kokkinaki, 1999). 
The results showed that the difference between the mean of actual behaviour was highly different between lowand high-involvement consumers. This result implies that the level of involvement can predict consumers' organic food product buying behaviour well. More specifically, that high-involvement consumers express more positive attitudes towards buying organic food products, perceive higher subjective norms and $\mathrm{PBC}$, along with higher behavioural intention, and buy organic food products more frequently. Additionally, the results indicated that, compared to low-involvement consumers, high-involvement consumers regard organic food products as more attractive, healthier, tastier, and with higher value. This also supports the literature on the subject (e.g., Tandon et al., 2020). Marketers therefore have a vested interest in increasing consumer involvement, and, among other things, they can do so by educating themselves (i.e., highlighting the benefits of consuming organic foods).

Regarding the price of organic food, logically, decreasing it would seem to be an easier short-term alternative, but high-involvement consumers believed that the price of organic food products is fair, consuming them is convenient, their certifications are trustworthy, and, they know a lot about organic products. Indeed, this result is more interesting because our research sample was practically uniform regarding their income, since 73.4 percent of the respondents had income of less than $€ 20.000$. Thus, we believe that the price relative to organic food products is not a barrier that greatly affects consumer behaviour, because high-involvement consumers believed that the price of organic food products is quite fair, and purchasing organic food products fits their budget. Hence, in the long-term, the increase of consumers' involvement would bring about more benefits to the producers and retailers of organic food products, especially in terms of income.

Another important finding of this paper is the confirmation that the level of involvement strongly moderates the influence of all antecedents of intention in the TPB model for low-involvement consumers. In other words, given that these consumers are not internally concerned with organic consumption, external influences (e.g., social norms, price, and knowledge) have a higher impact on their attitude, intention to buy, and thus their organic behaviour. It implies that a potentially successful strategy to increase organic consumption among low-involvement consumers is to underline and confirm the social norms and pressure associated with this type of consumption. More specifically, and proposed earlier, low-involvement consumers poorly rated these constructs, we can increase organic behaviour among these consumers through education and by justifying the higher price of organic food products, in turn, increasing their knowledge about the benefits for people and the environment. Faced with this reflection, promoting the clarity and reliability of organic certifications and labels, etc., can increase consumers' confidence, even their PBC, in this type of food.

Furthermore, we found that involvement moderates the intention-behaviour relationship so that the more the involvement with organic food products, the more the intention-behaviour consistency. This finding implies that increasing consumers' involvement with organic food products decreases the gap between intention to buy organic food products and the actual behaviour in this specific context. Based on the findings of this paper, we suggest promoting organic consumption through increasing consumers' involvement with organic food products. A short-term strategy could be to enhance involvement by stressing the personal benefits of organic food products, while in the long-term, involvement, and thus organic consumption, can be promoted by emphasizing the social and environmental importance of organic consumption. In fact, high-involvement consumers perceived the high value of organic food and they claimed to feel better by consuming it. They can therefore be allies for marketers through their influence (SN). Thus, we suggest the use of influencers on social media to endorse organic food. Existing literature shows that followers trust influencers on social media almost as much as their friends (Hudders et al., 2020). In this context, nano and micro-influencers would be preferable (1k-100k followers), because although they have less reach, the engagement rate of their followers is clearly higher than that of mega-influencers $(1 \mathrm{M}+$ followers) (Campbell \& Farrell, 2020).

\section{Limitation and Future Research}

Like most studies, this one is not free from limitations. Firstly, the sample of this study was comprised of French people, most of them were female, young, educated, with limited financial resources. Therefore, using a more diversified sample in terms of culture, age, education level, and income would increase the findings' generalizability. In this way, it would be interesting to conduct a cross-cultural study, comparing the different attitude-intention-behaviours between French and Canadian consumers. Past studies have demonstrated that consumers' attitudes toward buying organic food is strongly linked to values, lifestyles, green peers and beliefs, namely healthiness, taste and environmental friendliness (Khare \& Pankey, 2017; Thøgersen, 2016). Hence, consumers want to ensure that their food buying habits are in line with their personal values (Agriculture and AgriFood Canada, 2015). Given that culture can be defined as: "values, beliefs, norms, and behavioural patterns of a national group" (Leung et al., 2005), it can therefore be 
considered as a strong influencer of food consumption. Indeed, numerous studies assert that culture is one of the underlying determinants of attitude and behaviours (Ladhari et al., 2015). Thus, culture plays a key role in consumer choices (Cleveland et al., 2009).

Secondly, this study investigated the behaviour of organic food products as whole. Studying specific product categories may improve our understanding about organic consumption. Another limitation of this research is related to the use of self-report instead of objective and explicit measures. In addition, we acknowledge the shortcomings of our behavioural measure in our study. Initially, we wanted to have people listing the number of organic products purchased in the previous week as well as the amount of money spent, but the data were unusable. Therefore, we fell back on our back-up measure (retrospective measure on how much people agree with the fact that they had bought organic products in the last month (from 1 to 5). We realize that it is closer to intentions (declarative) even though the question concerns past behaviours, but it was the best possible proxy that we could use. These limitations should be easy to resolve in future research by observations or the analysis of secondary data from the industry. Moreover, the inclusion of health specialists' recommendations to subjective norms could be measured. As a result, Tarkiainen \& Sundqvist (2009) argued that attitudes toward organic food reflect health-related attitudes, and these attitudes are formed in accordance with health-related values. They found that health consciousness positively influenced attitudes towards organic food. As health consciousness could increase the motivation to comply with health specialists' recommendations, it is possible that conformity with health specialists' recommendations will positively influence attitudes toward organic food products. We have also mentioned that there is a causal path between subjective norms and attitudes towards behaviour (purchase intention) (Al-Swidi et al., 2014; Tarkiainen \& Sundqvist, 2005). However, the study did not make any relative assumptions in this regard. So, in the future, this assumption should be taken into consideration for more precise results regarding the TPB model about our study context.

Finally, we measured the involvement using only one item. Although this usage is sometimes controversial, we believe it is appropriate for our study. Indeed, Bergkvist \& Rossiter (2007) demonstrated that the single item measure had as high a predictive validity as the multiple item measure. Still, according to this line of thought, the usual reason for using multiple item scales is that they discriminate more by capturing more information. However,
Bergkvist and Rossiter (2007) showed that this was not the case, and more particularly about the validity of the basic constructs (e.g., attitude). Thus, the involvement representing a concrete concept in marketing justifies the use of a single item to measure it.

As mentioned in the introduction, the organic market, especially food consumption, is highly lucrative and has steadily risen over the past two decades (Massey et al., 2018; Statista, 2020). Furthermore, consumers have developed a more conscientious and positive attitude towards the consumption of organic foods than ever (Al-Swidi et al., 2014). The results of this study are therefore equally useful to academics as they are to the different actors in the organic sector and, ultimately, to consumers. While the gap between intention and behaviour is present, according to our extension of the TPB model, manufacturers, and distributors can better understand the organic purchasing decision process and now know they can count on the moderating role of consumer involvement in order to promote the relationship between attitude-intention, subjective norms-intention, PBC-intention, intention-behaviour and PBC-behaviour. This information is very relevant for marketers to improve the promotion of organic food consumption.

\section{Acknowledgements}

We would like to thank the Social Sciences and Humanities Research Council and the Fonds de recherche du Québec - Société.

\section{References}

Aertsens, J., Verbeke, W., Mondelaers, K., \& Van Huylenbroeck, G. (2009). Personal determinants of organic food consumption: A review. British Food Journal, 111(10), 1140-1167.

Agence Bio. (2020a). L'agriculture bio dans le monde (pp. 1-106).

Agence Bio. (2020b). Organic farming and market in the European Union (pp. 1-137).

Agriculture and Agri-Food Canada. (2015). Emerging food innovation: Trends and opportunities. Government of Canada, November.

Ajzen, I. (1985). From intentions to actions: A theory of planned behaviour. In J. Kuhl \& J. Beckmann (Eds.), Action Control (pp. 11-39). Springer.

Ajzen, I. (1988). Attitudes, personality, and behaviour. Dorsey Press.

Ajzen, I. (1991). The theory of planned behaviour. Organizational Behaviour and Human Decision Processes, 50(2), 179-211. 
Ajzen, I., \& Fishbein, M. (1980). Understanding attitudes and predicting social behaviour.

Al-Swidi, A., Huque, S. M. R., Hafeez, M. H., \& Shariff, M. N. M. (2014). The role of subjective norms in theory of planned behaviour in the context of organic food consumption. British Food Journal, 116(10), 1561-2158.

Armitage, C. J., \& Conner, M. (2001). Efficacy of the theory of planned behaviour: A meta-analytic review. British Journal of Social Psychology, 40(4), 471-499.

Aschemann-Witzel, J., \& Niebuhr Aagaard, E. M. (2014). Elaborating on the attitude-behaviour gap regarding organic products: Young Danish consumers and in-store food choice: In-store organic food choice. International Journal of Consumer Studies, 38(5), 550-558. https://doi.org/10.1111/ijcs. 12115

Bagozzi, R. P., \& Yi, Y. (1988). On the evaluation of structural equation models. Journal of the Academy of Marketing Science, 16(1), 74-94.

Baharrell, B., \& Denison, T. J. (1995). Involvement in a routine food shopping context. British Food Journal, 97(4), 24-29.

Baldauf, A., Cravens, K. S., Diamantopoulos, A., \& Zeugner-Roth, K. P. (2009). The impact of product-country image and marketing efforts on retailer-perceived brand equity: An empirical analysis. Journal of Retailing, 85(4), 437-452.

Bandura, A. (1977). Self-efficacy: Toward a unifying theory of behavioural change. Psychological Review, 84, 191-215.

Barber, N., Taylor, C., \& Strick, S. (2009). Wine consumers' environmental knowledge and attitudes: Influence on willingness to purchase. International Journal of Wine Research, 1(1), 59-72. https://doi.org/10.2147/ IJWR.S4649

Bartels, J., \& Reinders, M. J. (2010). Social identification, social representations, and consumer innovativeness in an organic food context: A cross-national comparison. Food Quality and Preference, 21(4), 347-352.

Beale, D. A., \& Manstead, A. S. R. (1991). Predicting mothers' intentions to limit frequency of infants' sugar intake: Testing the theory of planned behaviour. Journal of Applied Psychology, 25(5), 285-301.

Beatty, S. E., \& Smith, S. M. (1987). External search effort: An investigation across several product categories. Journal of Consumer Research, 14(1), 83-95.

Bentler, P. M. (2005). EQS 6 Structural Equations Program Manual. Multivariate Software.

Bentler, P. M., \& Bonett, D. G. (1980). Significance tests and goodness of fit in the analysis of covariance structures. Psychological Bulletin, 88(3), 588-606.
Berger, I. E., \& Mitchel, A. A. (1989). The effect of advertising on attitude accessibility, attitude confidence, and the attitude behaviour relationship. Journal of Consumer Research, 16(3), 269-279.

Bergkvist, L., \& Rossiter, J. R. (2007). The predictive validity of multiple-item versus single-item measures of the same constructs. Journal of Marketing Research, 44(2), 175-184. https://doi.org/10.1509/jmkr.44.2.175

Boccaletti, S., \& Nardellab, M. (2000). Consumer willingness to pay for pesticide-free fresh fruit and vegetables in Italy. The International Food and Agribusiness Management Review, 3(3), 297-310.

Britwum, K., Bernard, J. C., \& Albrecht, S. E. (2021). Does importance influence confidence in organic food attributes? Food Quality and Preference, 87, 104056. https://doi.org/10.1016/j.foodqual.2020.104056

Bryła, P. (2016). Organic food consumption in Poland: Motives and barriers. Appetite, 105, 737-746. https:// doi.org/10.1016/j.appet.2016.07.012

Campbell, C., \& Farrell, J. R. (2020). More than meets the eye: The functional components underlying influencer marketing. Business Horizons, 63(4), 469-479. https://doi.org/10.1016/j.bushor.2020.03.003

Celsi, R. L., \& Olson, J. C. (1988). The role of involvement in attention and comprehension processes. Journal of Consumer Research, 15(2), 210-224.

Chen, M. F. (2007). Consumer attitudes and purchase intentions in relation to organic foods in Taiwan: Moderating effects of food-related personality traits. Food Quality and Preference, 18(7), 1008-1021.

Chiou, J. S. (1998). The effects of attitude, subjective norm, and perceived behavioural control on consumers' purchase intentions: The moderating effects of product knowledge and attention to social comparison information. Proceedings of the National Science Council, Republic of China, 9(2), 298-308.

Chiu, T., Ortiz, J., Chih, W., Pang, L., \& Huang, J. (2019). Antecedents of consumers' citizenship behaviour towards organic foods. Journal of Consumer Behaviour, 18(4), 332-349. https://doi.org/10.1002/cb.1774

Cialdini, R.B., \& Goldstein, N. J. (1998). Social influence: Social norms, conformity, and compliance. $A n-$ nual Review of Psychology, 55(1), 591-621.

Clark, R. A., Haytko, D. L., Hermans, C. M., \& Simmers, C. S. (2019). Social influence on green consumerism: Country and gender comparisons between China and the United States. Journal of International Consumer Marketing, 31(3), 177-190. https://doi.org/10.1080/0 8961530.2018 .1527740

Cleveland, M., Laroche, M., Pons, F., \& Kastoun, R. (2009). Acculturation and consumption: Textures of cultural adaptation. International Journal of In- 
tercultural Relations, 33(3), 196-212. https://doi. org/10.1016/j.ijintrel.2008.12.008

Conner, M., \& Armitage, C. J. (1998). Extending the theory of planned behaviour: A review and avenues for further research. Journal of Applied Social Psychology, 28(15), 1429-1464.

Conner, M., \& Sparks, P. (1996). The theory of planned behaviour and health behaviours. Predicting Health behaviour: Research and practice with social cognition models (Conner M. \& Norman P., pp. 121-162). Open University Press.

Costa, A. I. A., Dekker, M., \& Jongen, W. M. F. (2004). An overview of means-end theory: Potential application in consumer-oriented food product design. Trends in Food Science \& Technology, 15(7-8), 403-415.

D’Astous, A., \& Legendre, A. (2009). Une étude exploratoire de quelques antécédents de la consommation socialement responsable (CSR). Revue Française $d u$ Marketing, 223(3/5), 39-51.

Dean, M., Raats, M. M., \& Shepherd, R. (2008). Moral concerns and consumer choice of fresh and processed organic foods. Journal of Applied Social Psychology, 38(8), 2088-2107.

Dowd, K., \& Burke, K. J. (2013). The influence of ethical values and food choice motivations on intentions to purchase sustainably sourced foods. Appetite, 69, 137-144.

Engel, J. F., \& Blackwell, R. D. (1982). Consumer behaviour. Dryden Press.

Fan, W., \& Yan, Z. (2010). Factors affecting response rates of the web survey: A systematic review. Computers in Human Behaviour, 26(2), 132-139.

Fishbein, M., \& Ajzen, I. (1975). Belief, attitude intention and behaviour. Addison-Wesley.

Fisher, A. R. H., \& De Vries, P. H. (2008). Everyday behaviour and everyday risk: An approach to study people's responses to frequently encountered food related health risks. Health Risk \& Society, 10(4), 385-397.

Flynn, L. R., \& Goldsmith, R. E. (1999). A short, reliable measure of subjective knowledge. Journal of Business Research, 46(98), 57-66. https://doi.org/10.1016/ S0148-2963(98)00057-5

Fornell, C., \& Larcker, D. F. (1981). Evaluating structural equation models with unobservable variables and measurement error: Algebra marketing research and statistics. Journal of Marketing Research, 18(1), 39-50.

Fotopoulos, C., \& Krystallis, A. (2002). Organic product avoidance: Reasons for rejection and potential buyers' identification in a countrywide survey. British Food Journal, 104(3/4/5), 233-260.

Geller, E. S. (1992). Solving environmental problems: A behaviour change perspective. In S. Staub \& P. Green
(Eds.), Psychology and social responsibility: Facing global challenges (pp. 248-268). New York University Press.

Gil, J. M., Gracia, A., \& Sánchez, M. (2000). Market segmentation and willingness to pay for organic products in Spain. The International Food and Agribusiness Management Review, 3(2), 207-226. https://doi. org/10.1016/S1096-7508(01)00040-4

Gleim, M. R., Smith, J. S., Andrews, D., \& Cronin, J. J. (2013). Against the green: A multi-method examination of the barriers to green consumption. Journal of Retailing, 89(1), 44-61. https://doi.org/10.1016/j. jretai.2012.10.001

Gottschalk, L., \& Leistner, T. (2013). Consumer reactions to the availability of organic food in discount supermarkets. International Journal of Consumer Studies, 37(2), 136-142.

Halkier, B., \& Bente, H. (1999). Consequences of the politicization of consumption: The example of environmentally friendly consumption practices. Journal of Environmental Policy \& Planning, 1(1), 25-41.

Härdle, W., \& Simar, L. (2007). Theory of estimation. Applied Multivariate Statistical Analysis (pp. 161-169).

Hjelmar, U. (2011). Consumers' purchase of organic food products. A matter of convenience and reflexive practices. Appitite, 56(2), 336-344.

Hofstede, G., \& Hofstede, G. H. (1984). Culture's consequences: International differences in work-related values (Vol. 5). Sage.

Hofstede, G., Hofstede, G. J., \& Minkov, M. (2005). Cultures and organizations: Software of the mind (Vol. 2). McGraw-Hill.

Hogg, M. A. (2020). Social identity theory. Stanford University Press.

Houme, K. P. (2009). Application de la théorie du comportement planifié pour prédire la persévérance des étudiants en sciences naturelles de l'Université de Lomé (Togo) [Doctoral dissertation]. Université Laval.

Hoyer, W. D. (1984). An examination of consumer decision-making for a common repeat purchase product. Journal of Consumer Research, 11(3), 822-829.

Hudders, L., De Jans, S., \& De Veirman, M. (2020). The commercialization of social media stars: A literature review and conceptual framework on the strategic use of social media influencers. International Journal of Advertising, 1-49. https://doi.org/10.1080/02650487. 2020.1836925

Huotilainen, A., Seppälä, T., Pirttilä-Backman, A. M., \& Tuorila, H. (2006). Derived attributes as mediators between categorization and acceptance of a new functional drink. Food Quality and Preference, 17(5), 328-336. 
Janssen, M. (2018). Determinants of organic food purchases: Evidence from household panel data. Food Quality and Preference, 68, 19-28. https://doi. org/10.1016/j.foodqual.2018.02.002

Jöreskog, K. G., \& Sörbom, D. (1996). LISREL 8: User's reference guide. Scientific Software International.

Katt, F., \& Meixner, O. (2020). A systematic review of drivers influencing consumer willingness to pay for organic food. Trends in Food Science \& Technology, 100, 374-388. https://doi.org/10.1016/j. tifs.2020.04.029

Kellar, I., \& Abraham, C. (2005). Randomized controlled trial of a brief research-based intervention promoting fruit and vegetable consumption. British Journal of Health Psychology, 10(4), 543-558.

Khare, A., \& Pankey, S. (2017). Role of green self-identity and peer influence in fostering trust towards organic food retailers. International Journal of Retail \& Distribution Management, 45(9), 969-990.

Kidwell, B., \& Jewell, R. D. (2003). An examination of perceived behavioural control: Internal and external influences on intention. Psychology \& Marketing, 20(7), 625-642.

Kline, R. B. (2005). Principles and practice of structural equation modelling. Guilford publications.

Klöckner, C. A., Matthies, E., \& Hunecke, M. (2003). Problems of operationalizing habits and integrating habits in normative decision-making models. Journal of Applied Social Psychology, 33(2), 396-417.

Kokkinaki, F. (1999). Predicting product purchase and usage. The role of perceived control, past behaviour and product involvement. In E. J. Arnould \& L. M. Scott (Eds.), Advances in Consumer Research (Vol. 26, p. 576-583). Advances in Consumer Research.

Kringelbach, M. L. (2004). Food for thought: Hedonic experience beyond homeostasis in the human brain. Neuroscience, 36(4), 807-819.

Krystallis, A., \& Chryssohoidis, G. (2005). Consumers' willingness to pay for organic food: Factors that affect it and variation per organic product type. British Food Journal, 107(5), 320-343.

Kushwah, S., Dhir, A., \& Sagar, M. (2019). Ethical consumption intentions and choice behaviour towards organic food. Moderation role of buying and environmental concerns. Journal of Cleaner Production, 236, 117519. https://doi.org/10.1016/j.jclepro.2019.06.350

Kushwah, S., Dhir, A., Sagar, M., \& Gupta, B. (2019). Determinants of organic food consumption. A systematic literature review on motives and barriers. Appetite, 143, 104402. https://doi.org/10.1016/j.appet.2019.104402
Ladhari, R., Souiden, N., \& Choi, Y. H. (2015). Culture change and globalization: The unresolved debate between cross-national and cross-cultural classifications. Australasian Marketing Journal, 23(3), 235-245. https://doi.org/10.1016/j.ausmj.2015.06.003

Laroche, M., Bergeron, J., \& Barbaro-Forleo, G. (2001). Targeting consumers who are willing to pay more for environmentally friendly products. Journal of Consumer Marketing, 18(6), 503-520.

Lee, H. J., \& Hwang, J. (2016). The driving role of consumers' perceived credence attributes in organic food purchase decisions: A comparison of two groups of consumers. Food Quality and Preference, 54, 141-151. https://doi.org/10.1016/j.foodqual.2016.07.011

Leung, K., Bhagat, R. S., Buchan, N. R., Erez, M., \& Gibson, C. B. (2005). Culture and international business: Recent advances and their implications for future research. Journal of International Business Studies, 36(4), 357-378.

Liu, M. E. (2007). US college students' organic food consumption behaviour [Doctoral dissertation]. Texas Tech University.

Lockie, S., Lyons, K., Lawrence, G., \& Mummery, K. (2002). Eating 'green': Motivations behind organic food consumption in Australia. Sociologia Ruralis, 42(1), 23-40.

Loureiro, S. M. C., Ruediger, K. H., \& Demetris, V. (2012). Brand emotional connection and loyalty. Journal of Brand Management, 20(1), 13-27. https:// doi.org/10.1057/bm.2012.3

Magnusson, M. K., Arvola, A., Ulla-Kaisa Koivisto, H., Lars, Å., \& Per-Olow, S. (2001). Attitudes towards organic foods among Swedish consumers. British Food Journal, 103(3), 209-227.

Mahon, D., Cowan, C., \& McCarthy, M. (2006). The role of attitudes, subjective norm, perceived control and habit in the consumption of ready meals and takeaways in Great Britain. Food Quality and Preference, 17(6), 474-481.

MAPAQ. (2015). Bottin statistique de l'alimentation 2015.

Massey, M., O'Cass, A., \& Otahal, P. (2018). A meta-analytic study of the factors driving the purchase of organic food. Appetite, 125, 418-427. https://doi. org/10.1016/j.appet.2018.02.029

McGorry, S. Y. (2000). Measurement in a cross-cultural environment: Survey translation issues. Qualitative Market Research: An International Journal, 3(2), 74-81. https://doi.org/10.1108/13522750010322070

Mittal, B. (1995). A comparative analysis of four scales of consumer involvement. Psychology \& Marketing, 12(7), 663-681. 
Nederhof, A. J. (1989). Self-involvement, intention certainty and attitude-intention consistency. British Journal of Social Psychology, 28(2), 123-133.

Ngobo, P. V. (2011). What drives household choice of organic products in grocery stores? Journal of Retailing, 87(1), 90-100.

Nunally, J. C. (1978). Psychometric theory. McGrawHill.

Oates, L., Cohen, M., \& Braun, L. (2012). Characteristics and consumption patterns of Australian organic consumers. Journal of the Science of Food and Agriculture, 92(14), 2782-2787.

Observatoire de la consommation responsable. (2016). Baromètre de la consommation responsable.

Onwezen, M. C., Bartels, J., \& Antonides, G. (2014). The self-regulatory function of anticipated pride and guilt in a sustainable and healthy consumption context, 44(1), 53-68.

Park, C., \& Moon, B. (2003). The relationship between product involvement and product knowledge: Moderating roles of product type and product knowledge type. Psychology \& Marketing, 20(11), 977-997.

Patch, C. S., Tapsell, L. C., \& Williams, P. G. (2005). Attitudes and intentions toward purchasing novel foods enriched with omega-3 fatty acids. Journal of Nutrition Education and Behavior, 37(5), 235-241.

Paternoster, R., Brame, R., Mazerolle, P., \& Piquero, A. (1998). Using the correct statistical test for the equality of regression coefficients. Criminology, 36(4), 859-866.

Peattie, K. J. (2010). Green consumption: Behaviour and norms. Annual Review of Environment and Resources, 35, 195-228.

Perrini, F. S., Casraldo, N, M., \& Tancati, A. (2010). The impact of corporate social responsibility associations on trust in organic products marketed by mainstream retailers: A study of Italian consumers. Business Strategy and the Environment, 19(8), 512-526.

Petersen, K. K., \& Dutton, J. E. (1995). Centrality, extremity, intensity neglected variables in research on attitude-behaviour consistency. Social Forces, 54(2), 393-414.

Petty, R. E., Cacioppo, J. T., \& Schumann, D. (1983). Central and peripheral routes to advertising effectiveness: The moderating role of involvement. Journal of Consumer Research, 10(2), 135-146.

Petty, R. E., Haugtvedt, C. P., \& Smith, S. M. (1995). Elaboration as a determinant of attitude strength: Creating attitudes that are persistent, resistant, and predictive of behaviour. Attitude Strength: Antecedents and Consequences, 4, 93-130.
Pieters, R., Baumgartner, H., \& Allen, D. (1995). A means-end chain approach to consumer goal structures. International Journal of Research in Marketing, 12(3), 227-244. https://doi.org/10.1016/01678116(95)00023-U

Rhodes, R. E., \& Courneya, K. S. (2003). Investigating multiple components of attitude, subjective norm, and perceived control: An examination of the theory of planned behaviour in the exercise domain. British Journal of Social Psychology, 42(1), 129-146.

Richins, M. L., \& Bloch, P. H. (1986). After the new wears off: The temporal context of product involvement. Public Relations Review, 13(2), 280-285.

Rodríguez-Bermúdez, R., Miranda, M., Orjales, I., Ginzo-Villamayor, M. J., Al-Soufi, W., \& López-Alonso, M. (2020). Consumers' perception of and attitudes towards organic food in Galicia (Northern Spain). International Journal of Consumer Studies, 44(3), 206-219. https://doi.org/10.1111/ijcs.12557

Rothschild, M. L., \& Gaidis, W. C. (1981). Behavioural learning theory: Its relevance to marketing and promotions. Journal of Marketing, 45(2), 70-78.

Rotter, J. B. (1954). Social learning and clinical psychology. Prentice-Hall.

Roussel,P. (2005). Méthodes de développementd'échelles pour questionnaires d'enquête. Management des Ressources Humaines: Méthodes de recherche en sciences humaines et sociales (pp. 245-276).

Saba, A., \& Messina, F. (2003). Attitudes towards organic foods and risk/benefit perception associated with pesticides. Food Quality and Preference, 14(8), 637-645.

Sapp, S. G. (1991). Impact of nutritional knowledge within an expanded rational expectations model of beef consumption. Journal of Nutrition Education, 23(5), 214-222.

Scalco, A., Noventa, S., Sartori, R., \& Ceschi, A. (2017). Predicting organic food consumption: A meta-analytic structural equation model based on the theory of planned behaviour. Appetite, 112, 235-248.

Schifferstein, H. N. J., \& OudeOphuis, P. A. M. (1998). Health-related determinants of organic food consumption in The Netherlands. Food Quality and Preference, 9(3), 119-133.

Shepherd, R., \& Raats, M. M. (1996). Attitudes and beliefs in food habits. Food Choice, Acceptance and Consumption (pp. 346-364). Springer.

Sparks, P., \& Shepherd, R. (2002). The role of moral judgments within expectancy-value-based attitude-behaviour models. Ethics \& Behaviour, 12(4), 299-321.

Statista. (2020). U.S. Organic Food Consumption and Industry - Statistics \& Facts. https://www.statista.com/ topics/1047/organic-food-industry/ 
Tabachnick, B. G., Fidell, L. S., \& Ullman, J. B. (2007). Using multivariate statistics (Vol. 5). Pearson.

Tae-Im, H., \& Stoel, L. (2017). Explaining socially responsible consumer behaviour: A meta-analytic review of theory of planned behaviour. Journal of International Consumer Marketing, 29(2), 91-103.

Tajfel, H. (1974). Social identity and intergroup behaviour. Social science information, 13(2), 65-93.

Tandon, A., Dhir, A., Kaur, P., Kushwah, S., \& Salo, J. (2020). Behavioural reasoning perspectives on organic food purchase. Appetite, 154, 104786. https://doi. org/10.1016/j.appet.2020.104786

Tarkiainen, A., \& Sundqvist, S. (2005). Subjective norms, attitudes and intentions of Finnish consumers in buying organic food. British Food Journal, 107(11), 808-822.

Tarkiainen, A., \& Sundqvist, S. (2009). Product involvement in organic food consumption: Does ideology meet practice? Psychology \& Marketing, 26(9), 844-863.

Temperini, V., Limbu, Y., \& Jayachandran, C. (2017). Consumers' trust in food quality and willingness to pay more for national parks' brands: Preliminary evidence from Italy. Journal of International Food \& Agribusiness Marketing, 29(2), 120-138.

Teng, C. C., \& Lu, C. H. (2016). Organic food consumption in Taiwan: Motives, involvement, and purchase intention under the moderating role of uncertainty. Appetite, 105, 95-105. https://doi.org/10.1016/j.appet.2016.05.006

Thøgersen, J. (2016). Consumer decision making with regard to organic food products. In Traditional food production and rural sustainable development (pp. 187-206). Routledge.

Towler, G., \& Shepherd, R. (1992). Application of Fishbein and Ajzen's expectancy-value model to understanding fat intake. Appetite, 19, 15-27.

Trafimow, D. (2000). Habit as both a direct cause of intention to use a condom and as a moderator of the attitude-intention and subjective norm-intention relations. Psychology and Health, 15(3), 383-393.

United State Department of Agriculture. (2016). Share of Consumer Expenditure Spent on Food. Our World in Data. https://ourworldindata.org
Van Kerckhove, A., Vermeir, I., \& Geuens, M. (2011). Combined influence of selective focus and decision involvement on attitude-behaviour consistency in a context of memory-based decision making. Psychology \& Marketing, 28(6), 539-560.

van Doorn, J., \& Verhoef, P. C. (2011). Willingness to pay for organic products: Differences between virtue and vice foods. International Journal of Research in Marketing, 28(3), 167-180.

Vassallo, M., Scalvedi, M. L., \& Saba, A. (2016). Investigating psychosocial determinants in influencing sustainable food consumption in Italy. International Journal of Consumer Studies, 40(4), 422-434.

Vermeir, I., \& Verbeke, W. (2006). Sustainable food consumption: Exploring the consumer "attitude - behavioural intention" gap. Journal of Agricultural and Environmental Ethics, 19(2), 169-194.

Welch, B. L. (1947). The generalization of "student's" problem when several different population variances are involved. Biometrika, 34(1/2), 28-35.

Wojciechowska-Solis, J., \& Soroka, A. (2017). Motives and barriers of organic food demand among Polish consumers: A profile of the purchasers. British Food Journal, 119(9), 2040-2048. https://doi.org/10.1108/ BFJ-09-2016-0439

Yiridoe, E. K., Bonti-Ankomah, S., \& Martin, R. C. (2005). Comparison of consumer perceptions and preference toward organic versus conventionally produced foods: A review and update of the literature. Renewable Agriculture and Food Systems, 20(4), 193-205.

Zaichkowsky, J. L. (1985). Measuring the involvement construct. Journal of Consumer Research, 12(3), 341-352. https://doi.org/10.1086/208520

Żakowska-Biemans, S. (2011). Polish consumer food choices and beliefs about organic food. British Food Journal, 113(1), 122-137.

Zanoli, R., \& Naspetti, S. (2011). Consumer motivations in the purchase of organic food: A means-end approach. British Food Journal, 104(8), 643-653.

Zegler, J. (2016). Food \& Drink Trends 2017. Mintel Group Ltd. https://www.mintel.com/blog/food-market-news/2017-global-food-drink-trends-how-didwe-do-12 


\section{Appendix 1. Item description and properties.}

\begin{tabular}{|c|c|c|c|}
\hline Construct & Items & Loading & Cronbach's alpha \\
\hline \multirow{7}{*}{ Attitude } & - Organic products are more attractive than conventional ones. & 0.712 & \multirow{7}{*}{0.902} \\
\hline & - Organic products are healthier than conventional ones. & 0.777 & \\
\hline & - Organic products are tastier than conventional ones. & 0.713 & \\
\hline & - Organic products are of a better value than conventional ones. & 0.826 & \\
\hline & - It is wise to buy organic products. & 0.815 & \\
\hline & - Eating organic products makes me feel good about myself. & 0.782 & \\
\hline & - My experience of consuming organic food was unenjoyable/enjoyable. & 0.774 & \\
\hline \multirow{2}{*}{ Subjective Norms } & - My friends think I should eat organic products. & 0.905 & \multirow{2}{*}{0.776} \\
\hline & - My family/partner/spouse think I should eat organic products. & 0.905 & \\
\hline \multirow{5}{*}{$\mathrm{PBC}$} & - The prices of organic products are fair. & 0.680 & \multirow{5}{*}{0.728} \\
\hline & - I know a lot about organic products. & 0.536 & \\
\hline & - I trust organic certifications. & 0.546 & \\
\hline & - Purchasing organic products fits my budget. & 0.750 & \\
\hline & - Consuming organic products is convenient. & 0.665 & \\
\hline \multirow{4}{*}{ Intention } & - I want to eat some organic products sometimes next month. & 0.944 & \multirow{4}{*}{0.941} \\
\hline & - I intend to eat some organic products over the next month. & 0.948 & \\
\hline & - I never/always eat organic products. & 0.890 & \\
\hline & $\begin{array}{l}\text { - The next time I go grocery shopping, it is very unlikely/very likely that I will choose } \\
\text { one or more organic product(s). }\end{array}$ & 0.915 & \\
\hline Involvement & - It is important to me to buy organic products. & & - \\
\hline \multirow{2}{*}{ Behaviour } & - I have bought at least one organic product in the last month. & 0.941 & \multirow{2}{*}{0.858} \\
\hline & - I've never/always bought organic products in the last month. & 0.941 & \\
\hline $\begin{array}{l}\text { Demographics } \\
\text { Characteristics }\end{array}$ & $\begin{array}{l}\text { - Are you female or male? } \\
\text { - How old are you? } \\
\text { - What was the last grade of school you completed? Primary school/High school/ } \\
\text { College-level/Academic education }\end{array}$ & - & - \\
\hline
\end{tabular}

